\title{
Hospital contacts for injuries and musculoskeletal diseases among seamen and fishermen: A population-based cohort study Linda Kaerlev*1,2, Anker Jensen ${ }^{3}$, Per Sabro Nielsen ${ }^{1,4}$, Jørn Olsen ${ }^{5}$, Harald Hannerz ${ }^{6}$ and Finn Tüchsen ${ }^{6}$
}

Address: ${ }^{1}$ Research Unit of Maritime Medicine at University of Southern Denmark, Esbjerg, Denmark, ${ }^{2}$ Linda Kærlev, Specialist in Occupational Medicine, Esbjerg, Denmark, ${ }^{3}$ Danish Defence, Occupational Health Center South, Fredericia, Denmark/Department of Occupational Health, Haderslev Hospital, Denmark, ${ }^{4}$ Department of Occupational Health, Esbjerg Hospital, Denmark, ${ }^{5}$ School of Public Health, Department of Epidemiology, The Southern California Injury Center, UCLA, LA, USA and ${ }^{6}$ National Institute of Occupational Health, Copenhagen, Denmark

Email: Linda Kaerlev* - L.Kaerlev@dadlnet.dk; Anker Jensen - ankerjensen@mil.dk;

Per Sabro Nielsen - Per.Sabro.Nielsen@svs.regionsyddanmark.dk; Jørn Olsen - jo@ucla.edu; Harald Hannerz - hha@arbejdsmiljoforskning.dk; Finn Tüchsen - ftu@arbejdsmiljoforskning.dk

* Corresponding author

Published: 23 January 2008

BMC Musculoskeletal Disorders 2008, 9:8 doi:10.1/86/147I-2474-9-8

Received: 27 February 2007

Accepted: 23 January 2008

This article is available from: http://www.biomedcentral.com/l47/-2474/9/8

(c) 2008 Kaerlev et al; licensee BioMed Central Ltd.

This is an Open Access article distributed under the terms of the Creative Commons Attribution License (http://creativecommons.org/licenses/by/2.0), which permits unrestricted use, distribution, and reproduction in any medium, provided the original work is properly cited.

\begin{abstract}
Background: We studied musculoskeletal diseases (MSD) and injuries among fishermen and seamen with focus on low back disorders, carpal tunnel syndrome (CTS), rotator cuff syndrome and arthrosis.

Methods: Cohorts of all male Danish seamen (officers and non-officers) and fishermen employed 1994 and 1999 with at least six months employment history were linked to the Occupational Hospitalisation Register. We calculated standardised incidence ratios (SIR) for the two time periods, using rates for the entire Danish workforce as a reference.

Results: Among fishermen, we found high SIRs for knee arthrosis, thoraco-lumbar disc disorders, injuries and statistically significant SIRs above 200 were seen for both rotator cuff syndrome and CTS. The SIR was augmented for injuries and reduced for hip arthrosis between the two time periods. The SIRs for injuries and CTS were high for non-officers. A sub-analysis revealed that the highest risk for CTS was found among male non-officers working as deck crew, SIR 233 (95\% Cl: 166-317) based on 40 cases. Among officers, the SIRs for injuries and MSDs were low. The number of employed Danish fishermen declined with 25\% 1994-1999 to 3470. Short-term employments were common. None of the SIRs increased with increasing length of employment.

Conclusion: Both fishermen and non-officers have high SIRs for injuries and fishermen also for MSD. Only the SIR for injuries among fishermen was augmented between 1994 and 1999. Our findings suggest an association between the incidence of rotator cuff syndrome and CTS and work within fishery. Long-term cumulative effects of employment were not shown for any of the disease outcomes. Other conditions may play a role.
\end{abstract}




\section{Background}

Studies from many countries have claimed that the occurrence of lesions and musculoskeletal disorders (MSD) among fishermen is generally high, although substantial national differences in the working conditions of the fishing industry do exist [1-13]. In a recent study among fishermen in the United States, musculoskeletal symptoms causing work disruption in the past 12 months were reported by $38.5 \%$, with low back symptoms accounting for $17.7 \%$, followed by pain in the hands or wrists and shoulders, each location accounting for $7 \%$ of the cases [14]. In a recent pilot interview study in 2004 among 39 Danish fishermen, rotator cuff syndrome and carpal tunnel syndrome seemed to be common problems but mainly among the older fishermen (age above 50) [15]. Depending on job title on board, the fishermen reports handling the ice and the catch as major physical demanding factors especially in the past due to lack of automatisation. Although ice bands and band conveyors has been introduced on many vessels, some fishermen who work with ice in the hold still have physically demanding repetitive work with their shoulder elevated during work. Such working postures are known to be risk factors for damage to the shoulder tendons [16]. Fishermen doing repair on the net are known to have repetitive hyperflexing and twisting movements of the wrists, which are risk factors for development of carpal tunnel syndrome [17]. Finally fishermen have a high incidence of traumatic injuries to the shoulder or wrist during fishery.

Although recent studies have shown that heredity is a dominant factor in lumbar disc degeneration, heavy lifting and awkward working positions as well as obesity and joint injury may be modest risk factors for disc degeneration, and also for arthrosis of the knee and hip [18,19]. Factors augmenting the working conditions were bad weather conditions, small crews and long working hours $[14,20,21]$. A high frequency of work-related diseases and injuries has been reported in earlier studies of seamen [22-24].

Fishing methods have continuously evolved throughout recorded history and especially in the recent decades advances in mechanization of gear handling, improved performances of vessels and motorization, computer technology, navigation aids and fish detection have been seen. Similarly, the Danish merchant fleet has modern ships, staffed mainly by native officers and a growing number of foreign crew. We would expect that improvements in mechanization would be reflected in a decline in incidence rates for MSDs for seamen and fishermen. However, several studies of fishermen have identified methodological difficulty inherent in identifying the population at risk and in following them up [9].
We aimed to study whether hospitalizations for thoracolumbar disc disorders, arthrosis of the knee and hip, rotator cuff syndrome, carpal tunnel syndrome and injuries were more common among seafarers (by job type) and fishermen than for other economically active Danes, comparing two employment time periods, 1994 and 1999, and whether the standardised incidence ratios (SIR) increased with length of service.

\section{Methods}

The present study population has already been described in detail $[25,26]$. Two five-year follow-up studies, one starting 1 January 1994 and the other 1 January 1999, were performed to examine potential changes over time in the SIRs of different diseases among Danish seamen and fishermen. A third follow-up study examined hospital contacts in the time period 1994-2003 as a function of length of service in the time period 1964-1993. Incidence rates were obtained by linking data from the Occupational Hospitalisation Register (OHR) to occupational cohorts extracted from the Danish Seafarer Registry (seamen) and from the fishing boat yearbooks, fishery yearbooks, the Danish Maritime Authority (DMA) files, tax and pension registries (fishermen) [23-28].

\section{Occupational cohorts}

The cohort of Danish seamen was based upon individual data files kept at the Danish Seafarer Register. This data source is administered by the DMA and is regarded as almost complete and suitable for research purposes [27]. It is compulsory for the shipping companies to send a copy of the employment contract to the DMA each time a seaman signs on and off a Danish ship. Such information is also kept for retired or deceased seamen. The Registry has been computerised since 1986 and it includes information on name, birthday, job title, name and call signal of the ship, and dates of start and end of each employment period.

The fishermen cohort was established by using different data sources, which we believe cover all professional fishermen in the country. Company information was extracted from fishing boat yearbooks, fishery yearbooks, the DMA files, and tax files. The aim was to identify all fishing boats in the Danish fishing industry operating from 1989 to 1998 , their owners and their company identification code. This code was used to extract employee data from the ATP Registry, the largest national pension scheme. The ATP holds data on the occupational history of each person employed on board all the registered fishing boats. It is compulsory for all companies in Denmark with employees working for 9 hours or more per week to participate in a non-contributory pension scheme. In addition, seamen and fishermen with a permanent address in Denmark also have a unique 10-digit Personal 
Identification Number (PIN), which has been assigned to each Danish resident since 1968. The number includes information on birthday and sex, and it is used by all authorities for registration purposes. We used the PIN to link the occupational data with each fisherman's or seaman's hospital contacts as an inpatient or outpatient as recorded by the nationwide Occupational Hospitalisation Register OHR [29].

\section{Inclusion criteria}

A total of 36,113 officers and non-officers of either gender (persons with and without residence in Denmark) and 11,755 male fishermen with a PIN were initially retrieved from the files of the DMA and the pension registry. Due to a high turn-over of the cohorts, we restricted the cohorts to include only those employed at two baselines at 1 January 1994 and at 1 January 1999 together with information about their job history with length of service within the trades. Short-term employments were common: $30.6 \%$ of the seamen and $41.9 \%$ of the fishermen had in 1989-1998 a total length of service of less than 6 months. We therefore made restrictions for the length of service in the definition of the occupational groups.

Inclusion criteria for follow-up of hospital contacts in the OHR during 1994-1998 were an age between 20 and 59 years on 1 January 1994, Danish residency according to the centralised person register, employment according to the employment classification module, and a total service as a seaman or fisherman of at least six months during 1989-1993 according to the occupational registers. The same inclusion criteria were used for the follow-up of hospital contacts in the OHR in 1999-2003, except that the starting date was 1 January 1999. This cohort consisted of individuals who were employed as seamen or fishermen 1 January 1999 and who had been in these occupations for at least 6 months during 1994-1998. There was a 32\% overlap between the two cohorts. A total of 10,231 seamen and 4,570 fishermen were included at baseline 1994 and followed up for diseases in the OHR 1994-1998 and 11,242 seamen and 3,470 fishermen were included at baseline 1999 and followed up for diseases in the OHR 1999-2003 (see Figure 1 and Table 1).

For the follow-up study on hospital contacts in the OHR in the time period 1994-2003 as a function of length of service in the time period 1964-1993 we included those with at least three months of service in the time period 1964-1993. We used the same inclusion condition as above with regard to employment status at the starting date 1 January 1994, and we added the conditions that a person had to be at least 30 years old and employed as a seaman or fisherman some time during 1993 (the year preceding the baseline date) (Figure 1).

\section{Occupational Hospitalisation Register}

The OHR holds information on each individual obtained through record linkage of three Danish national registers: The centralised civil registration system (CRS), the national hospital patient register and the employment classification module. The national hospital patient register has existed since 1977 and contains data from all national public hospitals (more than 99\% of all admissions). In the time period 1977-94, the register only included inpatients, but since 1995 it has also included outpatients and emergency ward visits [29]. Since 1994, the diagnoses have been coded according to the International Classification of Diseases, $10^{\text {th }}$ revision (ICD-10). The CRS contains information on gender, addresses and dates of birth, death and migration for every person who is or has been a Danish resident at any time between 1968 and present time. A person's employment status is registered annually in the employment classification module [30]. In Denmark, hospitals services are free of charge and the national health system is tax financed. For most of the population, a hospital is within a driving distance of 30 minutes or less.

\section{Follow-up for diagnoses in the Occupational Hospitalisation Register}

Each person was linked to the files of the nationwide OHR using the PIN. Observation began either on 1 January 1994 or 1 January 1999. The follow-up ended at the date of the hospitalisation for the diagnosis under study, date of death, date of emigration, or at the end of study (31 December 1998 or 31 December 2003), whichever came first. Person-years (PY) at risk were calculated for each individual.

A number of diagnoses were chosen for follow up because previous studies of seamen and fishermen or a recent pilot interview study among Danish fishermen have shown that they may be associated with these occupations [15]. The ICD-10 codes were selected before the study started and included the ICD-10 codes M00-M99 (diseases of the musculoskeletal system and connective tissue), M16 (arthrosis of the hip), M17 (arthrosis of the knee), M51 (thoraco-lumbar disc disorders), M75 (shoulder lesions), M75.1 (rotator cuff syndrome), S00-S99 + T00-T98 (injury, poisoning and certain other consequences of external causes), and G56 (carpal tunnel syndrome). The study was performed in accordance with the requirements of the Ethics Committees in Denmark.

\section{Statistical analyses}

All Danish ships were classified by a code in the registry according to their main use in the periods, e.g. passenger ship, gas tanker or product/chemical tanker. For each 5year period before start of follow-up, each study participant was assigned to the type of ship on board which he 


\section{Danish Seafarer Registry 1986-1998)}

( $n=36.113$ seamen)

Fishing boat yearbooks, fishery yearbooks, tax registries (fishery company codes) and pension registries (fishermen 1964- ) $(n=11.755$ fishermen)

- $\quad$ Exclusion of persons employed $<6$ months in the 5year time period preceding baseline.

- Exclusion of people not 20-59 years at baseline

- Exclusion of people not economically active at baseline according to OHR

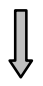

Exclusion of non-Danish residents and women

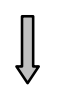

No. of persons by job type and time period 1994 (Table 2):

Men employed 1.1.1994

Age 20-59y

Length of service 1989 .

$1993>6$ months

Fishermen $(n=4.570)$

Officers $(n=5.061)$

Non-officers $(n=5.170)$

\begin{tabular}{|l|}
$\frac{\text { No. of persons by job }}{\text { type and time period }}$ \\
$\frac{1999 \text { (Table 2): }}{\text { Men employed 1.1.1999 }}$ \\
Age 20-59y \\
Length of service 1994- \\
$1998>6$ months \\
Fishermen $(n=3.470)$ \\
Officers $(n=5.375)$ \\
Non-officers $(n=5.867)$ \\
\hline
\end{tabular}

- Exclusion of persons employed < 3 months during 1964-1993.

- Exclusion of people not 20-59 years at baseline

- Exclusion of people not economically active at baseline according to OHR

- Exclusion of people not employed as fishermen or seamen 1993

No. of persons by job type (Table 3):
Men employed 1.1.1994
Age 20-59y
Length of service 1964-1993 >3 months
Fishermen ( $n=3.702)$
Officers ( $n=4.372)$
Non-officers ( $n=4.115)$
$\quad$ Exclusion of people aged < 30 years at baseline
No. of persons by job type and duration of employment (Table 3 ):
Men employed 1.1.1994
Age 30-59y
Length of service 1964-1993 >3 months
Fishermen ( $n=2.740)$
Officers ( $n=3.544)$
Non-officers $(n=2.450)$

\section{Figure I}

Selection of the study bases. Inclusion and exclusion criterias for the occupational cohorts of seafarers and fishermen (identified from registries with detailed information) and linkage to the Occupational Hospitalisation Register (OHR).

worked during his latest known employment within that 5 -year period. Evaluations also took into account the job title of the most recent employment before follow-up which was expected to reflect the seaman's social class membership. Data were only analysed for men.

The SIR was calculated as 100 multiplied by the ratio between the total number of observed cases with a specific hospital diagnosis and the total number of expected cases.
The latter was calculated by multiplying the PY at risk during the follow-up period in each five-year age and calendar year group by the corresponding sex-specific rates of hospital contacts among economically active people in the total Danish population. Their corresponding 95\% confidence intervals $(95 \% \mathrm{CI})$ were estimated assuming a Poisson distribution for the observed number of cases with a specific diagnosis. For the SIRs, we calculated exact intervals when the observed number of cases was less than 
Table I: Number and characteristics of Danish fishermen and seamen at baseline by gender and occupation, men

\begin{tabular}{|c|c|c|c|c|c|c|c|c|c|c|c|c|c|}
\hline \multirow[b]{4}{*}{ Characteristics } & \multirow{4}{*}{ Job type ${ }^{1}$} & \multicolumn{6}{|c|}{ Baseline I January 1994} & \multicolumn{6}{|c|}{ Baseline I January 1999} \\
\hline & & \multirow[t]{3}{*}{ Number } & \multirow[t]{3}{*}{ Mean age ${ }^{2}$ Years } & \multicolumn{4}{|c|}{ Vital status } & \multirow[t]{2}{*}{ Number } & \multirow[t]{3}{*}{ Mean age ${ }^{2}$ years } & \multicolumn{4}{|c|}{ Vital status } \\
\hline & & & & \multicolumn{2}{|c|}{ Alive $^{3}$} & \multicolumn{2}{|c|}{ Emigrated $^{4}$} & & & \multicolumn{2}{|c|}{ Alive $^{3}$} & \multicolumn{2}{|c|}{ Emigrated 4} \\
\hline & & & & $\mathrm{N}$ & $\%$ & $N$ & $\%$ & $N$ & & $N$ & $\%$ & $N$ & $\%$ \\
\hline Fishermen & Fishermen & 4570 & $37.2 \pm 9.8$ & 4468 & 97.8 & 58 & 1.3 & 3470 & $39.5 \pm 10.1$ & 3397 & 97.9 & 45 & 1.3 \\
\hline \multirow[t]{2}{*}{ Seamen } & Officers & 5061 & $40.2 \pm 10.0$ & 4942 & 97.7 & 167 & 3.3 & 5375 & $41.3 \pm 10.2$ & 5253 & 97.7 & 165 & 3.1 \\
\hline & Non-officers & 5170 & $35.0 \pm 11.1$ & 5037 & 97.4 & 192 & 3.7 & 5867 & $37.2 \pm 11.4$ & 5731 & 97.7 & $17 \mid$ & 2.9 \\
\hline
\end{tabular}

\footnotetext{
I Based on latest held employment before baseline.

2 Mean and standard deviation of age at baseline.

3 Number and percentage of people alive at the end of the follow-up period.

${ }^{4}$ Number and percentage of people having emigrated during the follow-up period.
}

100. Otherwise, we used the propagation of error formulas and normal approximation to estimate a 95\% CI around the logarithm of risk ratio, thereafter transforming it into a $95 \% \mathrm{CI}$ around the risk ratio. We controlled for age and county at baseline, and for the seamen we also controlled for type of ship (passenger ship versus other).

Length of service was divided into three categories approximately corresponding to tertiles. For fishermen we used the categories 3-71 months, 72-143 months, and >= 144 months based on income data from the pension registry. For seamen we used the categories 3-35 months, 36-71 months, and $>=72$ months since the data for seamen was based on actual days at sea and, 6 months at sea correspond to a full income year. The same categories were thus applied for fishermen and seamen. For each occupation, we estimated adjusted relative risks for hospital contacts according to length of service by means of a multiplicative Poisson regression model with no interaction using SAS software version 8.1. We controlled for age and county at baseline and for the seamen we also controlled for type of ship (Passenger ship versus all other categories of ships). We used a likelihood ratio test to test for significance of length of service.

\section{Results}

According to days at sea, the percentage of male seamen with permanent residence in Denmark (as a percentage of all Danish and non-Danish seamen on Danish ships) was $88 \%$ for officers, $90 \%$ for engineers, $77 \%$ for deck crew, $77 \%$ for engine crew, $75 \%$ for galley and catering crew, and $64 \%$ for other professions. Short-term employments were common: $30.6 \%$ of the seamen and $41.9 \%$ of the fishermen had in 1989-1998 a total length of service of less than 6 months. We therefore made restrictions to more than 6 months of service in the definition of the occupational groups before analyses (figure 1).

Among male fishermen working in 1999, we found an overall high SIR for MSDs, and sub-analysis revealed high SIRs for arthrosis of the knee, thoraco-lumbar disc disor- ders, shoulder diseases especially rotator cuff syndrome, and injuries. We found high SIR values for carpal tunnel syndrome among fishermen in both the 1994 and the 1999 cohort. The SIR ratio between the two time periods showed a decline in hospital contacts for hip arthrosis among fishermen and an increased risk for injuries in the same group.

Overall, the SIRs for MSD among male seamen working as non-officers did not differ from those seen among economically active men in general. Significantly high SIRs were found in the 1999 cohort for injuries and for carpal tunnel syndrome (Table 2). A sub-analysis revealed that the highest risk for carpal tunnel syndrome was found among non-officers working as deck crew, SIR 233 (95\% CI: 166-317) based on 40 cases (data not shown).

Officers had a statistically significant lower risk of MSD and injuries than economically active men at large.

We observed no statistically significant increase in the occurrence of any of the diseases under study among fishermen for the groups with middle ( 7 to 12 years) or long duration (more than 12 years) of employment compared with short length of employment (less than 6 years) (Table 3).

\section{Discussion}

Among male fishermen in 1999, we found an increased occurrence of injuries and MSD, and sub analysis showed increased SIRs for arthrosis of the knee, shoulder diseases, and carpal tunnel syndrome. Non-officer seamen had high SIRs for injuries and carpal tunnel syndrome, whereas officers had low SIRs. Long term cumulative effects of employment were not shown for any of the disease outcomes possibly suggesting a healthy worker effect.

The main strength of the present study is that it is based on a comparison between an old and a more recent cohort of seamen with the same type of employment details. Equally valid information was obtained for fishermen 
Table 2: Standardised incidence ratios (SIR) for muskuloskeletal diseases and injuries among male fishermen and seamen in Denmark by job type and time period

\begin{tabular}{|c|c|c|c|c|c|c|c|c|c|c|}
\hline \multirow[b]{2}{*}{$\mid C D-101$} & \multirow{2}{*}{$\begin{array}{l}\text { SIR by job type and time period } \\
\text { Disease }\end{array}$} & \multirow[b]{2}{*}{ Job type } & \multicolumn{3}{|c|}{$\begin{array}{l}\text { 1994-1998 SIR } 2 \text { ( } 4.570 \\
\text { fishermen, } 5.06 \text { I officers, } \\
5.170 \text { non-officers) }\end{array}$} & \multicolumn{3}{|c|}{$\begin{array}{l}\text { 1999-2003 SIR }{ }^{3}(3.470 \\
\text { fishermen, } 5.375 \text { officers, } \\
5.867 \text { non-officers) }\end{array}$} & \multirow[b]{2}{*}{ SIR ratio 4} & \multirow[b]{2}{*}{$95 \% \mathrm{Cl}$} \\
\hline & & & Cases & SIR & $95 \% \mathrm{Cl}$ & Cases & SIR & $95 \% \mathrm{Cl}$ & & \\
\hline \multirow[t]{3}{*}{ M00-M99 } & $\begin{array}{l}\text { Diseases of the musculoskeletal system } \\
\text { and connective tissue }\end{array}$ & Fishermen & 546 & 122 & $113-133$ & 494 & 118 & $108-129$ & 0.97 & $0.86-1.09$ \\
\hline & & Officers & 384 & 75 & $68-83$ & 499 & 75 & $69-82$ & 1.00 & $0.87-1.14$ \\
\hline & & Non-officers & 530 & 107 & $98-117$ & 730 & 106 & $98-114$ & 0.99 & $0.88-1.11$ \\
\hline \multirow[t]{3}{*}{ MI6 } & Arthrosis of the hip - Coxarthrosis & Fishermen & 17 & 162 & $95-260$ & 5 & 44 & $14-103$ & 0.27 & $0.10-0.73$ \\
\hline & & Officers & 8 & 51 & $22-101$ & 12 & 58 & $30-101$ & 1.13 & $0.46-2.76$ \\
\hline & & Non-officers & 5 & 45 & $15-106$ & 15 & 85 & $48-|4|$ & 1.89 & $0.69-5.19$ \\
\hline \multirow[t]{3}{*}{ MI7 } & Arthrosis of the knee - Gonarthrosis & Fishermen & 30 & 127 & $86-181$ & 37 & 144 & $101-198$ & 1.13 & $0.70-1.84$ \\
\hline & & Officers & 28 & 89 & $59-129$ & 45 & 102 & $74-136$ & 1.14 & $0.7 \mid-1.83$ \\
\hline & & Non-officers & 26 & 111 & $73-163$ & 42 & 110 & $80-149$ & 0.99 & $0.61-1.62$ \\
\hline \multirow[t]{3}{*}{ M5I } & Thoraco-lumbar disc disorders & Fishermen & 130 & 224 & $189-266$ & 78 & 178 & $|4|-222$ & 0.79 & $0.60-1.05$ \\
\hline & & Officers & 61 & 91 & $70-117$ & 63 & 92 & $7 I-118$ & 1.01 & $0.7 I-1.43$ \\
\hline & & Non-officers & 65 & 112 & $86-143$ & 81 & 122 & $97-|5|$ & 1.09 & $0.78-|.5|$ \\
\hline \multirow[t]{3}{*}{ M75 } & Shoulder lesions & Fishermen & 39 & 162 & || $5-22 \mid$ & 50 & 137 & $102-181$ & 0.85 & $0.56-1.29$ \\
\hline & & Officers & 25 & 87 & $56-129$ & 43 & 74 & $53-99$ & 0.84 & $0.52-1.38$ \\
\hline & & Non-officers & 24 & 95 & $6|-| 4 \mid$ & 66 & 115 & $89-147$ & 1.22 & $0.76-1.95$ \\
\hline \multirow[t]{3}{*}{ M75.I } & Rotator cuff syndrome & Fishermen & 20 & 225 & $138-348$ & 21 & 205 & $|27-3| 3$ & 0.91 & $0.49-1.68$ \\
\hline & & Officers & 9 & 84 & $38-159$ & 12 & 72 & $37-125$ & 0.86 & $0.36-2.03$ \\
\hline & & Non-officers & 10 & 106 & $51-195$ & 19 & 119 & $7 \mid-185$ & 1.12 & $0.52-2.41$ \\
\hline \multirow[t]{3}{*}{ S00-S99 } & $\begin{array}{l}\text { Injury, poisoning and certain other } \\
\text { consequences of external causes (single } \\
\text { body region) }\end{array}$ & Fishermen & 1611 & 112 & $107-118$ & 1377 & 120 & $114-126$ & 1.07 & $0.99-1.15$ \\
\hline & & Officers & 1081 & 68 & $65-73$ & 1286 & 67 & 64-7I & 0.98 & $0.90-1.06$ \\
\hline & & Non-officers & 1900 & 110 & $105-115$ & 2352 & 112 & $108-117$ & 1.02 & $0.96-1.09$ \\
\hline \multirow[t]{3}{*}{ Т00-Т98 } & $\begin{array}{l}\text { Injury, poisoning and certain other } \\
\text { consequences of external causes (more } \\
\text { than one body region) }\end{array}$ & Fishermen & 371 & 98 & $89-109$ & 357 & 118 & $106-130$ & 1.20 & $1.04-1.39$ \\
\hline & & Officers & 278 & 72 & $64-81$ & 316 & 69 & $62-77$ & 0.96 & $0.82-1.13$ \\
\hline & & Non-officers & 565 & 125 & $115-136$ & 649 & 120 & $111-129$ & 0.96 & $0.86-1.07$ \\
\hline \multirow[t]{3}{*}{ G56 } & Carpal tunnel syndrome & Fishermen & 48 & 315 & $233-418$ & 46 & 292 & $214-389$ & 0.92 & $0.62-1.39$ \\
\hline & & Officers & 11 & 63 & $31-113$ & 21 & 85 & $52-129$ & 1.34 & $0.65-2.79$ \\
\hline & & Non-officers & 26 & 168 & $109-246$ & 42 & 172 & $124-233$ & 1.03 & $0.63-1.67$ \\
\hline
\end{tabular}

1 International Classification of Diseases (ICD) version 10.

${ }^{2}$ At least 6 months employment 1989-1993. Follow-up of hospital contacts in 1994-1998. SIR adj. for county.

${ }^{3}$ At least 6 months employment 1994-1998. Follow-up of hospital contacts in 1999-2003. SIR adj. for county.

${ }^{4}$ Calculated if at least 5 cases were expected.

owing to the successful creation of a reliable fishermen cohort through a combination of several registries.

The possible disadvantages of the study were a high turnover of the cohort members and the lack of data on specific exposures. Approximately two thirds of the hospital contacts were outpatient visits. The level did not differ between seafarers and the population at large. The lack of information about outpatients in 1994 may have decreased the number of cases with MSD in this year, but this would be the case for both the seafarers and the rest of the Danish population (our comparison group). We have decided to keep the information on out-patients in the statistics, because we believe it gives valuable information. The number of Danish fishermen declined with 25\% between 1994 and 1999 as seen in Table 1. Since we only included fishermen and seamen with an active employment in 1994 and 1999, respectively, we do not expect that this have changed the results.

We used the economically active Danish population as a reference group in order to reduce a healthy worker effect. Referral bias may constitute a problem in studies using hospital admissions as a measure of disease, but especially for diseases commonly treated outside hospitals, e.g. back pain, and for diseases for which people are only admitted to hospital if it progresses to a severe disease [31]. We do not expect to have eliminated a healthy worker selection bias by using other employed people as a reference. Selection into the workforce is job-specific and the healthy worker effect may have been further enhanced by the obligatory health examinations for seamen. We therefore 


\begin{tabular}{|c|c|c|c|c|c|c|c|c|c|c|c|c|c|c|}
\hline \multirow[b]{2}{*}{ ICD-10' } & \multirow{2}{*}{$\begin{array}{l}\text { SIR by job type and duration of employment } \\
\text { Site }\end{array}$} & \multirow[b]{2}{*}{ Job type } & \multicolumn{3}{|c|}{$\begin{array}{l}\text { Overall SIR adj. county }{ }^{2}(3702 \\
\text { fishermen, } 4372 \text { officers, } 4 \text { II } \\
\text { non-officers) }\end{array}$} & \multicolumn{2}{|c|}{$\begin{array}{l}\text { Short duration }{ }^{3} \text { (100I } \\
\text { fishermen } 2252 \text { officers, } 1173 \\
\text { non-officers }\end{array}$} & \multicolumn{3}{|c|}{$\begin{array}{l}\text { Med. duration } 3,4 \text { ( } 1136 \text { fishermen, } \\
1030 \text { officers, } 974 \text { non-officers) }\end{array}$} & \multicolumn{2}{|c|}{$\begin{array}{l}\text { Long duration } 3,5 \text { ( } 603 \\
\text { fishermen, } 262 \text { officers, } 303 \\
\text { non-officers) }\end{array}$} & \multirow[b]{2}{*}{$95 \% \mathrm{Cl}$} & \multirow[b]{2}{*}{ Prob ChiSq } \\
\hline & & & Cases & SIR & $95 \% \mathrm{Cl}$ & Cases & $\mathrm{RR}$ & Cases & $\mathrm{RR}$ & $95 \% \mathrm{Cl}$ & Cases & $\mathrm{RR}$ & & \\
\hline M00-M99 & $\begin{array}{l}\text { Diseases of the musculoskeletal system and } \\
\text { connective tissue }\end{array}$ & Fishermen & 830 & 124 & $116-132$ & 241 & 1.0 & 287 & 1.04 & $0.87-1.23$ & 122 & 0.80 & $0.64-0.99$ & 0.0433 \\
\hline M00-M99 & & Officers & 684 & 80 & $74-86$ & 396 & 1.0 & 139 & 0.72 & $0.59-0.88$ & 49 & 1.02 & $0.74-1.39$ & 0.0029 \\
\hline M00-M99 & & Non-officers & 849 & 111 & $104-119$ & 292 & 1.0 & 209 & 0.81 & $0.68-0.97$ & 54 & 0.61 & $0.45-0.83$ & 0.0017 \\
\hline MI6 & Arthrosis of the hip & Fishermen & 18 & 75 & $44-118$ & 3 & 1.0 & 9 & 2.38 & $0.65-8.80$ & 6 & 2.35 & $0.59-9.39$ & 0.3287 \\
\hline MI6 & & Officers & 21 & 57 & $35-87$ & 16 & 1.0 & 2 & - & - & 3 & - & - & - \\
\hline MI6 & & Non-officers & 14 & 58 & $32-98$ & 9 & 1.0 & 4 & - & - & - & - & - & - \\
\hline MI7 & Arthrosis of the knee & Fishermen & 69 & 121 & $94-153$ & 23 & 1.0 & 31 & 1.09 & $0.64-1.87$ & 11 & 0.62 & $0.30-1.27$ & 0.2311 \\
\hline MI7 & & Officers & 63 & 94 & $72-120$ & 39 & 1.0 & 16 & 0.84 & $0.47-1.51$ & 5 & 0.94 & $0.35-2.51$ & 0.8381 \\
\hline MI7 & & Non-officers & 56 & 117 & $88-151$ & 28 & 1.0 & 18 & 0.68 & $0.37-1.24$ & 3 & 0.33 & $0.10-1.12$ & 0.1033 \\
\hline M5I & Thoraco-lumbar disc disorders & Fishermen & 178 & 185 & $160-215$ & 50 & 1.0 & 68 & 1.17 & $0.81-1.69$ & 21 & 0.68 & $0.41-1.13$ & 0.0751 \\
\hline M5I & & Officers & 99 & 90 & $74-110$ & 55 & 1.0 & 18 & 0.69 & $0.40-1.18$ & 12 & 1.78 & $0.91-3.48$ & 0.0498 \\
\hline M5I & & Non-officers & 102 & 110 & $91-134$ & 43 & 1.0 & 22 & 0.59 & $0.35-1.00$ & 7 & 0.57 & $0.25-1.31$ & 0.0930 \\
\hline M75 & Shoulder lesions & Fishermen & 80 & 139 & $110-172$ & 25 & 1.0 & 24 & 0.81 & $0.46-1.42$ & 16 & 0.98 & $0.52-1.84$ & 0.7240 \\
\hline M75 & & Officers & 57 & 80 & $60-103$ & 35 & 1.0 & 14 & - & - & 2 & - & - & - \\
\hline M75 & & Non-officers & 81 & 137 & $109-170$ & 34 & 1.0 & 23 & 0.75 & $0.44-1.29$ & 5 & 0.51 & $0.19-1.35$ & 0.2881 \\
\hline M75.I & Rotator cuff syndrome & Fishermen & 36 & 160 & $|12-22|$ & 9 & 1.0 & 13 & - & - & 8 & - & - & - \\
\hline M75. I & & Officers & 19 & 84 & $5|-| 3 \mid$ & 10 & 1.0 & 4 & - & - & 2 & - & & - \\
\hline M75. I & & Non-officers & 27 & 143 & 94-208 & 11 & 1.0 & 9 & - & - & 2 & - & - & \\
\hline S00-S99 & $\begin{array}{l}\text { Injury, poisoning and certain other consequences } \\
\text { of external causes (single body region) }\end{array}$ & Fishermen & 1999 & 140 & $134-146$ & 517 & 1.0 & 609 & 1.04 & $0.93-1.17$ & 259 & 0.83 & $0.72-0.96$ & 0.0066 \\
\hline S00-S99 & & Officers & 1574 & 71 & $68-75$ & 766 & 1.0 & 368 & 1.05 & $0.93-1.19$ & 79 & 0.89 & $0.70-1.13$ & 0.3799 \\
\hline S00-S99 & & Non-officers & 2206 & 109 & $105-114$ & 583 & 1.0 & 445 & 0.92 & $0.82-1.05$ & 124 & 0.77 & $0.63-0.95$ & 0.0375 \\
\hline T00-T98 & $\begin{array}{l}\text { Injury, poisoning and certain other consequences } \\
\text { of external causes (more than one body region) }\end{array}$ & Fishermen & 569 & 143 & $132-155$ & 155 & 1.0 & 151 & 0.87 & $0.69-1.08$ & 67 & 0.77 & $0.58-1.02$ & 0.1629 \\
\hline T00-T98 & & Officers & 445 & 75 & 68-82 & 220 & 1.0 & 83 & 0.84 & $0.65-1.09$ & 27 & 1.17 & $0.77-1.78$ & 0.2454 \\
\hline T00-T98 & & Non-officers & 753 & 122 & $|13-13|$ & 216 & 1.0 & 135 & 0.76 & $0.61-0.95$ & 32 & 0.57 & $0.39-0.84$ & 0.0028 \\
\hline G56 & Carpal tunnel syndrome & Fishermen & 88 & 267 & $214-328$ & 29 & 1.0 & 27 & 0.78 & $0.46-1.32$ & 12 & 0.73 & $0.37-1.44$ & 0.5497 \\
\hline G56 & & Officers & 28 & 70 & $47-102$ & 19 & 1.0 & 8 & - & - & 1 & - & - & - \\
\hline G56 & & Non-officers & 56 & 180 & $136-234$ & 24 & 1.0 & 13 & - & - & 6 & - & - & - \\
\hline $\begin{array}{l}1 \text { Internat } \\
2 \text { In the ca } \\
3 \text { In the an } \\
\text { reference } \\
4 \text { Medium } \\
5 \text { Long du }\end{array}$ & $\begin{array}{l}\text { onal Classification of Diseases (ICD) version } \\
\text { Iculation of the overall SIR we included peo } \\
\text { alysis of risk as a function of duration of emp } \\
\text { duration of employment corresponding to } \\
\text { ation of employment corresponding to mor }\end{array}$ & $\begin{array}{l}0 . \\
\text { who were }> \\
\text { yment we in } \\
2 \text { years of in } \\
\text { than } 12 \text { years }\end{array}$ & $\begin{array}{l}P=20 \text { yea } \\
\text { cluded } p e \\
\text { icome. } \\
\text { s of incon }\end{array}$ & . & ere $>=3$ & 0 years. Short & ion o & mploym & corr & ding to & ss than 6 yea & & was used as & \\
\hline
\end{tabular}


expect our results to be biased towards low estimates for some of the diseases we studied. Admission of seamen and fishermen to hospitals in other countries may take place for acute diseases and accidents and low risks are therefore not easily interpreted. We expect that Danish seamen and fishermen are generally referred to treatment at Danish hospitals since medical treatment is free in Denmark. Hospitalisation abroad that is not followed by hospitalisation in Denmark will bias risk estimate towards null. The threshold for hospital contacts generally differs within a population, and we expect people working at sea to have a higher threshold for hospitalisation for most of the diseases studied in this paper due to their long working periods. Still, we found an increased incidence of hospitalisation due to injuries among both fishermen and non-officers. Among fishermen, the SIRs for injuries were increased in 1999 and the SIR ratio for hospital contacts for these conditions rose between the two time periods.

Despite pre-employment selection, we found high hospitalisation rates in the 1999 cohort for knee arthrosis and lumbar disc disorders among fishermen compared with economically active men in general, but that may be due to a difference in the hospitalisation threshold over time. Biomechanical analysis of fishermen on fishing vessels from Sweden revealed that ship motions were mainly counteracted by motions in the lower extremity and lumbar back and induced increased strain here when subjects were standing erect [32]. Holding a load considerably increased the pressure on most joints. Other papers have shown that symptoms from the musculoskeletal system were common and correlated with age, number of years in the fishing trade, type of fishing and type of work on board [20,21,33]. Work tasks implying severe workload included handling the fishing gear and handling the catch. In a Swedish study, musculoskeletal symptoms were one of the major reasons for leaving the job as a fisherman [34]. All fishermen in Denmark have access to compensation if they are forced to quit their job due to work-related illness, especially back pain after many years of heavy lifting. Our finding of arthrosis of the knee among fishermen, but not among seamen, may be due to differences in the size of the ships, the relative stability of the ship at sea, work tasks or employment time. Injuries or a high body-mass index may also be a risk factor for arthrosis of the knee among fishermen, but our data did not allow us to examine this hypothesis [9]. Since 20022003 it has in Denmark also been compulsory for fishermen to pass the health examinations, and the requirements of "fit for duty" are now the same as for seamen. Back in time it is possible that the situation was different. An earlier study of 299 seamen referred to an orthopaedic clinic for knee pathology found that $51 \%$ of these patients had a diagnosis of knee osteoarthritis [35]. Genu varus or bow legs were present in $31 \%$ of the seamen studied.
Our finding of a high SIR for shoulder diseases among fishermen is backed by data from a recent study showing that shoulder crepitation tended to be more common among fishermen than among welders $[10,14]$. The findings of a nearly 2-fold elevated SIRs for carpal tunnel syndrome and rotator cuff syndrome among fishermen are new. These associations were present in both cohorts and may be real. A high incidence of traumatic injuries to the shoulder or wrist during fishery or in the spare time may partly explain the finding, but our data did not allow us to investigate this hypothesis further, since only major injuries is expected to be treated at hospitals. Fishermen are also known to have repetitive hyperflexing and twisting movements of the wrists in cold surroundings (when doing repair on the net or tearing fish out of the net), which may explain the wrist symptoms, and physically demanding repetitive work with their shoulder elevated during work with ice in the hold may explain the damage to the shoulder tendons.

Male non-officers had increased SIRs for injuries as shown in previous studies. An increased incidence of injuries compared with the general population indicates that injuries and lesions remain a problem in this trade, even for modern ships [36]. Officers, on the other hand, have less physically demanding work, and we would therefore expect rates for these diseases to be lower and at levels corresponding to those encountered for white collar workers on shore. The increased SIR for carpal tunnel syndrome among non-officers working as deck crew may be due to work with hand-vibrating tools on board (during corrosion repair work) [17]. Other possible explanations were former injuries of the wrist, other working processes or exposures in the spare time.

\section{Conclusion}

Fishermen still have increased SIRs for injuries and MSDs and the SIR was augmented for injuries and reduced for hip arthrosis between the two time periods. Our findings suggest an association between work within fishery and the incidence of shoulder lesions, rotator cuff syndrome and carpal tunnel syndrome. Among non-officers the SIRs for injuries and carpal tunnel syndrome were high. A subanalysis revealed that the highest risk for carpal tunnel syndrome was found among male non-officers working as deck crew. Officers have low SIRs for injuries and MSDs. The number of employed Danish fishermen declined with $25 \%$ between 1994 and 1999 to 3470. Short-term employments are common in the trades. None of the SIRs increased with increasing length of employment in any of the three trades. Whether these diseases were caused by physically demanding repetitive work, injuries or other conditions among fishermen and seamen needs to be confirmed in studies with more detailed exposure data and confounding control. 


\section{Competing interests}

The author(s) declare that they have no competing interests.

\section{Authors' contributions}

All authors (LK, AJ, PSN, JO, HH, FT) participated in the design and coordination of the study. LK applied for funding, carried out the data collection, prepared the dataset for statistical analyses and drafted the manuscript. JO helped to draft the manuscript. $\mathrm{HH}, \mathrm{FT}$ and LK performed the statistical analysis. All authors (LK, AJ, PSN, JO, HH, FT) read, commented and approved the manuscript.

The national research Centre for the Working Environment contributed reference data from the Occupational Hospitalisation register collected and organized by Elsa Bach, FT, and $\mathrm{HH}$

\section{Acknowledgements}

This study was supported financially by a grant from the Danish Research Agency (grant 22-03-05I8) and the Danish Health Insurance Foundation.

\section{References}

I. Jaremin B, Kotulak E, Starnawska M, Mrozinski W, Wojciechowski E: Death at sea: certain factors responsible for occupational hazard in Polish seamen and deep-sea fishermen. Int J Occup Med Environ Health 1997, 10:405-416.

2. Jensen OC, Stage S, Noer P, Kaerlev L: Risk assessment in fishery. Classification of working processes to facilitate occupational hazard coding on industrial trawlers. Am J Ind Med 2003, 44:424-30.

3. Jensen OC: Mortality in Danish fishermen. Bull Inst Marit Trop Med Gdynia 1996, 47:5-10.

4. Jensen OC: Work related injuries in Danish fishermen. Occup Med 1996, 46:4I4-20.

5. Wagner B: Safety and health in the fishing industry. Int Marit Health 2003, 54:I5I-63.

6. Thomas TK, Lincoln JM, Husberg BJ, Conway GA: Is it safe on deck? Fatal and non-fatal workplace injuries among Alaskan commercial fishermen. Am J Ind Med 200I, 40:693-702.

7. Grainger CR: Hazards of commercial fishing. World Health Forum 1993, 14:313-5.

8. Fugelli P, Toft J]: [Do fishermen often suffer from illness? Health problems in fishermen]. Tidsskr Nor Laegeforen 1984, 1 04:2465-8

9. Matheson C, Morrison S, Murphy E, Lawrie T, Ritchie L, Bond C: The health of fishermen in the catching sector of the fishing industry: a gap analysis. Occup Med (Lond) 200 I, $5 \mathrm{I}: 305-\mathrm{I} I$.

10. Torner M, Zetterberg C, Anden U, Hansson T, Lindell V: Workload and musculoskeletal problems: a comparison between welders and office clerks (with reference also to fishermen). Ergonomics 1991, 34: II79-96.

I I. Filikowski J, Rzepiak M, Renke W: Health problems of deep sea fishermen. Bull Inst Marit Trop Med Gdynia 1998, 49:45-5I.

12. Filikowski J, Krynicki A: Estimation of the health condition of deep-sea fishermen based on examination of their actual morbidity. Bull Inst Marit Trop Med Gdynia 1979, 30:175-87.

13. Casson FF, Zucchero A, Boscolo Bariga A, Malusa E, Veronese C, Boscolo Rizzo P, Chiereghin F, Boscolo Panzin C, Mancarella P, Mastrangelo G: Work and chronic health effects among fishermen in Chioggia, Italy. G Ital Med Lav Ergon 1998, 20:68-74.

14. Lipscomb HJ, Loomis D, McDonald MA, Kucera K, Marshall S, Li L: Musculoskeletal symptoms among commercial fishers in North Carolina. Appl Ergon 2004, 35:4l7-26.

15. Kærlev L: Fiskeri og helbred. Et pilot studie. Esbjerg, 2005 (in Danish), Fishery and health, a pilot study.

16. Svendsen SW, Bonde JP, Mathiassen SE, Stengaard-Pedersen K, Frich LH: Work related shoulder disorders: quantitative exposure- response relations with reference to arm posture. Occup Environ Med 2004, 6 I:844-53.

17. Palmer KT, Harris EC, Coggon D: Carpal tunnel syndrome and its relation to occupation: a systematic literature review. Occup Med (Lond) 2007, 57:57-66. Epub 2006 Nov 2

18. Videman T, Levälahti E, Battié MC: The effects of anthropometrics, lifting strength, and physical activities in disc degeneration. Spine 2007, 32:1406-13.

19. Lau EC, Cooper C, Lam D, Chan VN, Tsang KK, Sham A: Factors associated with osteoarthritis of the hip and knee in Hong Kong Chinese: obesity, joint injury, and occupational activities. Am J Epidemiol 2000, I 52:855-62.

20. Torner M, Blide G, Eriksson H, Kadefors R, Karlsson R, Petersen I: Workload and ergonomics measures in Swedish professional fishing. Appl Ergon 1988, 19:202-12.

21. Torner M, Blide G, Eriksson H, Kadefors R, Karlsson R, Petersen I: Musculo-skeletal symptoms as related to working conditions among Swedish professional fishermen. Appl Ergon 1988, 19:191-201.

22. Jensen O, Sorensen JFL, Kaerlev L, Canals ML, Nikolic N, Saarni H: Self-reported injuries among seamen. Questionnaire validity and results from an international study. Accid Anal Prev 2004, 36:405-13.

23. Kaerlev L, Hansen J, Hansen HL, Nielsen PS: Cancer incidence among Danish seamen - A population-based cohort study. Occup Environ Med 2005, 62:761-765.

24. Hansen HL, Tüchsen F, Hannerz H: Hospitalization among seamen on merchant ships. Occup Environ Med 2005, 62: I45-I50.

25. Kaerlev L, Dahl S, Nielsen PS, Olsen J, Hannerz H, Jensen A, Tüchsen $\mathrm{F}$ : Hospital contacts for chronic diseases among Danish seamen and fishermen - A population-based cohort study. Scand J Pub Health 2007, 35:48I-489.

26. Kaerlev L, Jensen A, Nielsen PS, Olsen J, Hannerz H, Tüchsen F: Hospital contacts for noise related hearing loss among Danish seafarers and fishermen - A population-based cohort study. Noise and Health 2008 in press.

27. Hansen HL: Occupation-related morbidity and mortality among merchant seamen with particular reference to infectious diseases. Esbjerg: South Jutland University press, Institute of Maritime Medicine; 1996.

28. Silver Star Reklame, Denmark: Danmarks Kutternøgle. Skagen 2000.

29. Tüchsen F, Bach E, Marmot M: Occupation and hospitalization with ischaemic heart diseases: a new nationwide surveillance system based on hospital admissions. Int J Epidemiol 1992, $21: 450-9$.

30. Soll-Johanning H, Hannerz H, Tuchsen F: Referral bias in hospital register studies of geographical and industrial differences in health. Dan Med Bull 2004, 5 I:207-10.

31. Tuchsen F, Andersen O, Olsen J: Referral bias among health workers in studies using hospitalization as a proxy measure of the underlying incidence rate. J Clin Epidemiol 1996, 49:79|-4.

32. Torner M, Almstrom C, Karlsson R, Kadefors R: Working on a moving surface - a biomechanical analysis of musculo-skeletal load due to ship motions in combination with work. Ergonomics 1994, 37:345-62.

33. Torner M, Zetterberg C, Hansson T, Lindell V, Kadefors R: Musculoskeletal symptoms and signs and isometric strength among fishermen. Ergonomics 1990, 33: I 155-70.

34. Torner MI, Nilsson E, Kadefors R: The influence of musculo-skeletal load, and other factors, on staff turn-over in fishery: a post employment questionnaire study. Bull Inst Marit Trop Med Gdynia 1990, 41:97-108.

35. Pearce MS, Buttery YE, Brueton RN: Knee pathology among seamen: a review of 299 patients. Occup Med (Lond) 1996, 46: $137-40$

36. Hansen HJ, Nielsen D, Frydenberg M: Occupational accidents aboard merchant ships. Occup Environ Med 2002, 59:85-91.

\section{Pre-publication history}

The pre-publication history for this paper can be accessed here:

http://www.biomedcentral.com/1471-2474/9/8/prepub 